\title{
Immunhistochemical Expression of Galectin-3 in Cancer: A Review of the Literature
}

\author{
Kanser Vakalarında İmmünohistokimyasal Galektin-3 Ekspresyonu: \\ Literatür Taraması
}

\author{
Tuğçe ÇAY
}

Gül 06-05 B:26 D:4 Bahçeşehir, ISTANBUL, TURKEY

\begin{abstract}
Galectin-3 is a $\beta$-galactoside-binding animal lectin that contains carbohydrate-recognition domains and displays multiple related functions. It has important roles in diverse biological events, such as embryogenesis, growth, cell adhesion, proliferation, differantiation, cell-cycle progression, apoptosis, mRNA splicing, and regulation of the immune system. Galectin-3 is expressed in various cells and tissues, such as activated macrophages, eosinophils, neutrophils, mast cells, epithelium of the gastrointestinal and respiratory tracts, kidneys and some sensory neurons, and is also involved in tumorigenesis, angiogenesis, and tumor metastasis. In this review of the literature, immunohistochemical Galectin-3 expression is investigated in numerous tumors and disorders of various organ systems.
\end{abstract}

Key Words: Galectin-3, Immunohistochemistry, Cancer

\begin{abstract}
ÖZ
Galektin-3, $\beta$-galaktoside bağlanan hayvansal bir tür lektindir ve karbonhidrat tanıyan bölgeler içerir. Birbirleriyle ilişkili birçok fonksiyonu vardır. Embriyogenez, büyüme, hücre adezyonu, proliferasyonu, diferansiasyonu, hücre-siklus progresyonu, apoptozis, mRNA bölünmesi ve bağıșıklık sisteminin düzenlenmesi biyolojik fonksiyonlarından bazılarıdır. Aktive olmuş makrofajlar, eozinofiller, nötrofiller, mast hücreleri, gastrointestinal ve solunum sistem epiteli, böbrekler ve bazı duyu nöronları gibi farklı hücre ve dokularda Galektin-3 gözlenmektedir. Tümör oluşumu, anjiyogenez ve tümör metastazında rolü vardır. Bu literatür taramasında, immünohistokimyasal olarak Galektin-3 ekspresyonu çok sayıda farklı organın tümör ve hastalıklarında araştırılmıştır.
\end{abstract}

Anahtar Sözcükler: Galektin-3, İmmünohistokimya, Kanser

\section{INTRODUCTION}

Galectin-3 is a $\beta$-galactoside-binding animal lectin that contains carbohydrate-recognition domains and displays multiple related functions (1). Galectin-3 is comprised of three distinct structural domains: a short NH2-terminal domain containing a serine phosphorylation site, a repeated collagen alpha-like sequence, and a $\mathrm{COOH}$-terminal domain containing a single carbohydrate recognitionbinding domain. The collagen alpha-like sequence contains a cleavage site at the Ala62-Tyr63 peptide bond for matrix metalloproteinases (MMP-2 and MMP-9) (2).

Fourteen members of the galectin family have been identified to date. Galectin-3 is a $31-\mathrm{kDa}$ gene product that serves as an intracellular and extracellular lectin and that is thought to interact with glycoproteins located on the cell surface matrix (3). Galectin-3 has important roles in diverse biological events, such as embryogenesis, growth, cell adhesion, proliferation, differentiation, adhesion, cell-cycle progression, apoptosis, mRNA splicing, and

Received : 22.01.2011

Accepted : 29.03.2011 regulation of the immune system. Galectin-3 is expressed in various cells and tissues, such as activated macrophages, eosinophils, neutrophils, mast cells, epithelium of the gastrointestinal and respiratory tracts, kidneys and some sensory neurons, and is also involved in tumorigenesis, angiogenesis, and tumor metastasis $(1,3,4)$. Extracellular Galectin-3 mediates inflammation, whereas intracellular Galectin-3 regulates cell growth and anti-apoptosis, and modulates cell adhesion, thus inducing cell migration (1).

In this literature review, immunohistochemical Galectin-3 expression is investigated in numerous tumors and disorders of various organ systems; like endocrine organs, gastrointestinal system, female genital tract, urinary tract, central nervous system, respiratory tract, head and neck region, breast, gallbladder and many other different and interesting sites.

\section{DISCUSSION}

Galectin-3, which has received significant recent attention for its utility as a diagnostic marker for thyroid cancer,

Correspondence: Tuğçe ÇAY

Gül 06-05 B:26 D:4 Bahçeşehir, İSTANBUL, TURKEY

E-mail: tugcecay@yahoo.com Phone: +90 2126690226 
represents the most well-studied molecular candidate for thyroid cancer diagnosis. Chiu et al. in their study investigated the utilization of Galectin-3 as a thyroid cancer diagnostic marker. According to this study, immunohistochemical Galectin-3 protein expression was a sensitive, specific, and accurate marker for the diagnosis of thyroid cancer. Galectin-3 was highly expressed in thyroid cancer, but not in normal thyroid tissue, and infrequently in benign thyroid lesions. They found that, Galectin-3 might also represent an attractive target for therapy of thyroid cancer. Disaccharide methyl $\beta$-lactosaminide analogues were developed and evaluated for their ability to selectively block binding of Galectin-3 to Galectin-3 binding glycoproteins (5). Koo et al. investigated in their study, the immunohistochemical features of diffuse sclerosing variant of papillary carcinoma, which were different from those of papillary thyroid carcinoma. Galectin-3 was expressed in all cases of conventional papillary thyroid carcinoma, but 16.3\% cases of diffuse sclerosing variant of papillary carcinoma did not express Galectin-3 and as a result of these findings they suggested that, diffuse sclerosing variant of papillary carcinoma was immunohistochemically Galectin-3 negative (6). Zhu et al. studied CK-19, RET, Galectin-3 and HBME-1 expression in papillary thyroid carcinoma and found that expression in papillary thyroid carcinoma was higher than that in benign disease cases, but they concluded that, these were not specific markers for papillary thyroid carcinoma (7). Also Barut et al. studied the same markers in the diagnosis and differential diagnosis of benign and malignant thyroid lesions. They suggested that, the use of Galectin-3, HBME-1, and CK-19 might provide significant contributions in the differential diagnosis of malignant thyroid tumors. Although focal Galectin-3, HBME-1, and CK-19 expression might be encountered in benign lesions, diffuse positive reactions for these three markers were characteristic of malignant lesions (8). Torregrossa et al. evaluated the diagnostic use of protein expression of CXC chemokine receptor 4 (CXCR4) and Galectin-3 that were found to be upregulated in papillary thyroid carcinoma compared to normal thyroid and of mesothelial cell surface protein recognized by monoclonal antibody HBME-1 in thyroid tumors. Expression of each individual marker was significantly associated with malignancy, although the sensitivity of detection ranged from $56 \%$ for Galectin-3 to $94 \%$ for HBME- 1 . As a result of these findings, they concluded that, an immunohistochemical panel, including Galectin-3 and CXCR4, could be useful in the differential diagnosis between benign and malignant well-differentiated follicular-patterned thyroid lesions (9). Saussez et al. studied Galectin-3,-7, and -8 in Warthin's tumor. Using immunohistochemical fingerprinting with members of the family of adhesion/growth-regulatory galectins and comparison to intra- and interlobular ducts, marked similarities were noted for presence of Galectins-3, -7 , and -8 and profiles of lectin binding, determined by applying human lectins as probes, were also similar when testing biotinylated Galectins-3 and -8 (10). Ersoz et al. studied Galectin-3 expression in thyroid fine needle aspiration cytology and found that Galectin-3 expression in thyrocytes was a strong indicator of a malignant proliferative lesion especially for papillary and to an extent in follicular thyroid neoplasms and could be used as a supplementary marker for cytological diagnosis. Galectin-3 immunocytochemical staining had a sensitivity of $61.5 \%$, specificity of $100 \%$ for thyroid malignancies and for the evaluation of follicular neoplasm, it had a sensitivity of $60 \%$, specificity of $100 \%$ (11). Fassan et al. studied an uncommon type of thyroid tumor. Primary thyroid squamous cell carcinoma was explored using a large panel of antibodies including Galectin-3. No immunostaining was detected for Galectin-3 (12).

Hyperplastic and neoplastic parathyroid lesions may present overlapping morphologic features. It is frequently difficult to establish histologically whether a parathyroid tumor is a parathyroid carcinoma, parathyromatosis, or an atypical adenoma. Fernandez-Ranvier et al. tried to define a molecular phenotype for benign and malignant parathyroid tumors and asked in their study, whether these tumors had a distinctive molecular profile, whether benign tumors could be distinguished from malignant tumors, and whether parathyromatosis was a low-grade parathyroid carcinoma or benign tissue that could invade other organs. They found any single diagnostic marker that could determine whether a parathyroid tumor was a parathyroid carcinoma, but loss of parafibromin and $\mathrm{Rb}$ expression, and overexpression of Galectin-3, generally distinguished parathyroid carcinoma from other parathyroid tumors and parathyromatosis did not appear to be a low-grade parathyroid carcinoma (13). Saggiorato et al. studied Galectin-3 and Ki-67 expression in multiglandular parathyroid lesions. Their data showed that hyperplastic lesions responsible for primary nonfamilial or tertiary hyperparathyroidism, as well as parathyroid adenomas were negative for Galectin-3, as opposed to carcinomas. Secondary and familial primary hyperplasia cases were surprisingly positive for Galectin-3 and all hyperplastic lesions (positive or negative for Galectin-3) had a low Ki-67 index. As a result of these findings they concluded that secondary hyperplasia had a low proliferative potential but an unexplained Galectin-3 reactivity, which reduced its diagnostic role in differentiating benign from malignant nodules in the context of multiglandular parathyroid diseases. They demonstrated that in multiglandular parathyroid diseases, nonfamilial primary hyperplasia and tertiary adenoma had the same Galectin-3/ 
Ki-67 expression pattern as single adenomas, whereas multiglandular parathyroid diseases in the setting of MEN syndrome or secondary hyperparathyroidism, despite a low Ki-67 proliferative index, expressed Galectin-3 protein, possibly as the result of a peculiar genetic or metabolic background (14). Bergero et al. studied Galectin-3 expression in parathyroid carcinoma comparing with parathyroid adenoma and showed Galectin-3 was expressed in $92.3 \%$ of parathroid carcinomas, and $3.3 \%$ of parathroid adenomas. All metastasizing parathyroid carcinomas were Galectin-3-positive. They concluded that, Galectin-3 immunostaining was a valuable tool to support a diagnosis of parathyroid carcinoma in highly proliferating (Ki67 $>6 \%$ ) tumors affecting a single parathyroid gland (15).

Galectin-3 expression correlates with tumor progression in several types of cancers. Arfaoui-Toumi et al. investigated the involvement of Galectin-3 in colorectal cancer development by immunohistochemical analysis of Galectin-3 expression in term of intensity and distribution in normal mucosa, in primary tumor and in metastasis, also compared the Galectin-3 staining according to the histological subtype (mucinous vs non mucinous), tumoral differentiation and stage of tumor. They concluded that, Galectin-3 played an important role in colorectal cancer progression concerning the non mucinous carcinoma and could be used as a prognostic factor to predict poor outcome of patients. They showed a strong and diffuse positive staining of Galectin-3 in both adjacent and distanced normal mucosa, in well differentiated adenocarcinoma and in metastasis. However, they noted a progressive decrease of Galectin-3 staining according to the decreasing degree of tumoral differentiation. They also observed a loss of this protein in adenocarcinoma with mucinous component $<50 \%$, where the positive staining was limited only to the well differentiated areas of tumor (16). Wu et al. explored the correlation between the expressions of Galectin-3 and lymph node metastasis of colon cancer and concluded that Galectin-3 expression was higher in tumors with lymph node metastasis than the tumors without metastasis and it might serve as a prognostic indicator for colon cancer patients (17). Huang et al. observed the expression of Galectin-3 in the liver metastasis of colon cancer in mice and found that the expression of Galectin-3 was significantly increased in the liver metastasis of colon cancer (18).

Miyazaki et al. studied Galectin-3 expression in primary gastric carcinoma and lymph node metastasis. They concluded that, Galectin-3 might be a useful tumor marker for gastric cancers with respects to tumor progression and potentiality of lymph node metastasis especially in certain histological types of gastric cancer. A significantly stronger expression of Galectin-3 in cancer tissues was only observed in papillary and poorly differentiated adenocarcinoma. When Galectin-3 expression and tumor progression (TNM staging) was compared, a significant correlation was observed in overall cases, and only in poorly differentiated adenocarcinoma the Galectin-3 expression correlated with tumor progression among various subtypes. Galectin-3 expression was observed significantly stronger in metastatic lymph nodes than in the primary gastric cancers, and also in these cases among histological subtypes, only in poorly differentiated adenocarcinoma, the expression of Galectin-3 in metastatic lymph nodes was stronger than the primary cancer (19). Zhou et al. also studied Galectin-3 expression in benign and malignant lesions of stomach and showed that the positive rates of Galectin-3 were significantly higher in gastric cancer tissues than those in peritumoral tissues and different types of benign lesions. They found no difference between the primary foci and metastatic foci in Galectin-3 expression and concluded that the expressive levels of Galectin-3 may be important for reflecting the carcinogenesis, progression and biological behaviors in gastric cancer (20). Okada et al. showed in their study that, reduced Galectin-3 expression was associated with lymph node metastasis, advanced stage and tumor differentiation in gastric cancer (21). Yang et al. declared the same conclusion in their study in which the association between the expression of Galectin- 3 and the peritoneal metastasis in gastric cancer were examined (22).

Shibata et al. studied impact of nuclear Galectin-3 expression in esophageal squamous cell carcinoma. They found that, high expression of Galectin-3 in the nuclei inversely correlated with vascular invasion and histological differentiation. In contrast, cytoplasmic expression of Galectin-3 revealed no significant impact on clinicopathological factors. They concluded that, elevated expression of Galectin-3 in the nuclei but not the cytoplasm might be an important biological parameter related to histological differentiation and vascular invasion in patients with esophageal squamous cell carcinoma (23).

Galectin-3 expression in inflammatory bowel disease is an other investigation field. Brazowski et al. investigated the presence of Galectin-3(+) macrophages in pouch mucosa in patients with ulcerative colitis who underwent ileal pouchanal anastomosis. They found that, Galectin-3 staining was restricted to $\mathrm{CD} 68(+)$ macrophages and not present in myofibroblasts and clinical manifestation of pouchitis was inversely correlated with Galectin-3 expression in the pouches' subepithelial lamina propria macrophages (24). Muller et al. also studied Galectin-3 in inflammatory bowel disease and their aim was to determine Galectin-3 expression in the normal and inflamed intestinal mucosa and to define its role in $T$ cell activity. They found that, in the 
normal mucosa, Galectin-3 protein was mainly observed in differentiated enterocytes, preferentially at the basolateral side. However, Galectin-3 was significantly downregulated in inflamed biopsies from inflammatory bowel disease patients. According to their study results, downregulation of epithelial Galectin-3 in the inflamed mucosa reflected a normal immunological consequence, whereas under noninflammatory conditions, its constitutive expression could help to prevent inappropriate immune responses against commensal bacteria or food compounds. Therefore, Galectin-3 could prove valuable for manipulating disease activity (25).

Galectin-3 expression in tumors of the ovary is another interesting investigation area. Lee et al. studied Galectin-3 expression in mucinous tumours of the ovary. They concluded that Galectin-3 expression was more frequent in clear cell carcinomas, serous tumours and mucinous tumours than in endometrioid and transitional tumours. However, there were no differences in Galectin-3 expression in comparisons among benign, borderline and malignant mucinous and serous tumours (26). Brustmann et al. studied Galectin-3 in serous ovarian carcinoma and found that Galectin-3 immunostaining decreased from serous cystadenomas and serous borderline ovarian tumors to the carcinomas significantly and Galectin-3 immunostaining of any pattern (nuclear and cytoplasmic as well as merely cytoplasmic taken together) was not related to grade or stage in cancers; mere cytoplasmic expression was associated with poor outcome (27). Oishi et al. studied Galectin-3 expression in clear cell carcinoma of the ovary and whether Galectin-3 had any contribution on Cisplatin resistance. Their immunohistochemical staining showed that Galectin-3 expression in clear cell carcinoma of the ovary was significantly more frequent than that of serous adenocarcinoma of ovary. They concluded that, the expression of Galectin-3 in clear cell carcinoma of the ovary might contribute to its lower cell proliferation and lead to Cisplatin resistance (28).

Devouassoux-Shisheboran et al. investigated expression of Galectin-3 in gonads and gonadal sex cord stromal and germ cell tumors. In their study they showed that, in human ovaries, Galectin-3 was absent from granulosa cells, as well as from granulosa cell and Sertoli-Leydig cell tumors, and was not a useful marker in distinguishing granulosa cell from Sertoli-Leydig cell tumors. In human testes, Galectin-3 was specifically expressed in mature Sertoli cells and Leydig cells, and was absent from fetal and pre-pubertal testes, suggesting a hormone-dependence of this gene. In testicular tumorigenesis, Galectin-3 had a dual function according to the histological type of tumors and their hormone dependency. In malignant testicular Sertoli cell tumors, the expression of Galectin-3 was down-regulated while, in benign Leydig cell tumors, this expression was maintained, indicating the possible implication of this gene in the development of more aggressive testicular sex cord stromal tumors. In contrast to sex cord stromal tumors, Galectin-3 expression was up-regulated in testicular germ cell tumors. By real-time PCR, they demonstrated a significant elevation of the Galectin-3 mRNA level in nonseminomatous testicular germ cell tumors and cell line as compared to normal testes and seminomas, indicating the possible role of this gene in the non-seminomatous differentiation of germ cell tumors (29).

In the trophoblast of the gestational trophoblastic disease, Galectin-3 expression was investigated by Bozic et al. They showed that a large proportion of the transformed trophoblast cells of all gestational trophoblastic disease studied were positive for Galectin-3. Immunoreactivity for Galectin-3 in gestational trophoblastic disease was increased in which immunoreactivity was scored semiquantitatively to include both the prevalence among the trophoblast cells and the intensity of staining. This finding suggested a possible implication of Galectin-3 in the invasiveness of the transformed trophoblastic cell, although the exact physiological significance of this finding remained to be determined (30).

Endometriosis is another interesting area that Galectin-3 expression is investigated. In Noel et al. study, the expression of Galectin-3 had been carried out by immunohistochemistry, according to the different phases of cycle in peritoneal, ovarian and deeply infiltrating endometriosis and in eutopic endometrium without endometriosis and with endometriosis. In the proliferative and secretory phases of the cycle, the nuclear and membranous Galectin-3 expression was higher, first in each variant of the endometriosis than in the eutopic endometrium, and second in the eutopic endometrium of women with endometriosis than in eutopic endometrium of women without endometriosis. Their data suggested that Galectin-3 might have a potential role in the development of endometriosis (31).

Lee et al. investigated whether the expression of Galectin-3 was associated with the progression of cervical neoplasia in female genital tract. They showed the expression of Galectin-3 was downregulated in cervical cancer tissues and suggested that the decreased expression of this galactosidebinding lectin was associated with the progression of cervical neoplasia (32).

Brustmann et al. studied Galectin-3 in vulvar squamous lesions (normal squamous epithelia-NE, vulvar condylomas$\mathrm{VC}$, high grade vulvar intraepithelial neoplasias of common 
type-HG_VIN, and invasive keratinizing squamous cell carcinomas-SCC). Galectin-3 expression was cytoplasmic, nuclear or membranous in NE, VCs, and HG_VINs, with negative or weak and occasionally moderate reactivities. In SCCs, exclusively cytoplasmic staining patterns with moderate or strong reactivity were observed); Galectin-3 expression as not related with stage, grade, and recurrence (33).

Galectin-3 expression is investigated also in urinary system. Kramer et al. searched Galectin-3 in pTa bladder cancer. They concluded that loss of Galectin-3 appeared to be involved in the carcinogenesis of transitional cell carcinoma and to serve as a valuable biological variable to identify a subgroup of pTa bladder cancer patients at high risk for the development of recurrent disease (34).

Galectin-3 expression in renal neoplasms was studied by Dancer et al. They showed that, Galactin-3 was strongly overexpressed in renal cell neoplasms of distal tubular differentiation, that was, oncocytoma and chromophobe renal cell carcinomas, suggesting it might be used as a possible differential diagnostic tool for renal cell neoplasm with oncocytic or granular cells. Furthermore, they observed a strong association of overexpression of Galectin-3 and high nuclear grade in clear cell renal cell carcinomas. These results also suggested a possible pivotal role for Galectin-3 in the differentiation and prognosis of clear cell renal cell carcinoma (3). Merseburger et al. studied Galectin-3 in clear cell renal cell carcinoma. In their study, in normal kidney tissue, the expression of Galectin-3 was found to be uniformly present in the tubular epithelial cells and a decrease of antigen expression levels were significantly associated with higher tumor stages and unfavourable longterm prognosis. Univariate analysis could demonstrate an association with tumor-specific death with decreased Galectin-3 expression, whereas multivariate analysis failed to prove the aforementioned observation. Their results suggested that loss of Galectin-3 expression was involved in renal carcinogenesis (35). Sakaki et al. investigated the same topic as Galectin-3 expression in clear cell renal cell carcinoma. Galectin-3 expression level in clear cell renal cell carcinoma was significantly higher than that in renal parenchyma obtained from the same patient samples. Galectin-3 expression in clear cell renal cell carcinoma with distant metastasis was also significantly higher than that in clear cell renal cell carcinoma without distant metastasis. They revealed that Galectin-3 was highly expressed in clear cell renal cell carcinoma, especially in clear cell renal cell carcinoma with distant metastasis, suggesting that Galectin-3 might serve as a novel target molecule for predicting clear cell renal cell carcinoma metastasis (36).
Merseburger et al. studied Galectin-3 expression in prostate cancers. In their study, Galectin-3 expression was significantly decreased in the hormone-sensitive prostate cancers specimens when compared with the respective benign tissue either localized far distant from the malignant lesion or directly neighboring the primary tumor. The staining reaction in the benign tissue areas directly neighboring the primary cancerous lesions differed significantly from the benign glands localized distant from the primary tumors. Almost complete loss of Galectin-3 was observed in the hormone-refractory when compared with the hormone-sensitive tumors. Their investigation clearly indicated that, decreased expression of Galectin-3 to be substantially involved in the pathogenesis and further progression of prostate cancers from benign prostate glands to a finally hormone-refractory malignant disease (37). Wang et al. investigated Galectin-3 in prostate cancers and immunohistochemical analysis of Galectin-3 expression revealed that Galectin-3 was cleaved during the progression of prostate cancer. Galectin-3 knockdown led to cellcycle arrest at G1 phase, up-regulation of nuclear p21, and hypophosphorylation of the retinoblastoma tumor suppressor protein $(\mathrm{pRb})$, with no effect on cyclin D1, cyclin E, cyclin-dependent kinases (CDK2 and CDK4), and p27 protein expression levels. This data implicated Galectin-3 in prostate cancer progression and suggested that Galectin-3 might serve as both a diagnostic marker and therapeutic target for future disease treatments (38).

Ostalska-Nowicka et al. analysed the immunohistochemical expression of Galectin-3 in renal biopsy specimens of children with idiopathic nephrotic syndrome. In the control, minimal change disease and diffuse mesangial proliferation children who responded to steroid therapy anti-Galectin-3 reactivity was present both in renal cortex and medulla. It was the strongest within cortical collecting ducts and subjectively less expressed in distal tubules. The total number of Galectin-3 positive cortical and medullary segments of collecting ducts was significantly higher in the subjects who did not respond to steroid therapy These patients revealed also immunohistochemical reactivity of Galectin-3 within nuclei of individual glomerular mesangial cells. They concluded that, Galectin-3 in mature human glomeruli during proteinuric glomerulopathies might indicate, on the one hand, its anti-inflammatory effect, but on the other could prognosticate a further glomerular reconstruction leading to focal segmental glomerulosclerosis. Taken together, both glomerular and extraglomerular Galectin-3 immunoreactivity in certain diffuse mesangial proliferation individuals could be regarded as the factor of unfavourable prognosis (39).

Galectin-3 is a useful biomarker for differential diagnosis of brain tumors. Park et al. investigated Galectin-3 expression 
in primary brain tumors. According to this study, in normal brain tissues, Galectin-3 was robustly expressed in normal astrocytes, endothelial cells and macrophages. It showed consistent and diffuse positivity in $100 \%$ of the pilocytic astrocytomas, pleomorphic xanthoastrocytomas, Schwannomas, meningiomas, capillary hemangioblastomas, as well as in ependymomas, but it was completely negative in the diffuse astrocytomas, anaplastic astrocytomas, both low- and high-grades of the oligodendrogliomas, central neurocytomas, and medulloblastomas. Definitely positive but heterogeneous expression was found in various tumors including subependymal giant cell astrocytomas, classic glioblastoma multiforme, anaplastic oligoastrocytomas, CNS primitive neuroectodermal tumors, and hemangiopericytomas. Eighty percent of small cell glioblstomas were completely negative, but $20 \%$ showed heterogeneous positivity for Galectin-3. Focal positivity for Galectin-3 was also found in dysembryoplastic neuroepithelial tumors and gangliogliomas, in which the positive cells were the astrocytic component (40).

Borges et al. investigated Galectin-3 expression in the differential diagnosis of posterior fossa tumors in children. According to their study, Galectin-3 was differentially expressed in pediatric posterior fossa tumors, but its expression showed no correlation with patient outcome. The evaluation of Galectin-3 was helpful in establishing a differential diagnosis among pediatric posterior fossa tumors, especially between pilocytic astrocytomas (strong Galectin-3 expression) and diffuse astrocytomas (no immunostaining of Galectin-3), and in some circumstances between medulloblastomas (no immunostainingof Galectin-3) and atypical teratoid/rhabdoid tumors (Galectin-3 expression heterogeneous, being mainly observed in rhabdoid cells) (41). Rodriguez et al. also studied Galectin-3 expression in nervous system and they concluded that, although Galectin-3 positivity was a key feature of the immunophenotype of spindle cell oncocytoma, its consistent expression in other morphologically similar tumors (meningioma, pituicytoma, nerve sheath tumors, granular cell tumor, metastases) made it of little use in the differential diagnosis of sellar region tumors, a setting in which it should be discouraged. Diagnostic uses of this marker might be limited to specific settings, including some meningioma subtypes and nerve sheath tumors (42).

Galectin-3 expression is studied specifically in pituitary adenomas. Huang et al. were one of the investigators of this topic. In their study they showed that, Galectin-3 might function through a cell death inhibition pathway involving Bcl-2 to enhance cell proliferation, which resulted in the invasive growth of pituitary adenoma. These results indicated that, Galectin-3 had an important role in pituitary tumor cell proliferation and might serve as a possible therapeutic target in treatment of pituitary tumors (43). Jin et al. studied Galectin-3 expression in silent and functioning ACTH and prolactin (PRL) producing adenomas. They found that, Galectin-3 was associated with functioning ACTH and PRL tumors and was expressed infrequently in silent ACTH adenomas, suggesting that Galectin-3 protein and/or gene was altered in non-functioning ACTH tumors. The use of ACTH and Galectin-3 immunostaining should help in the diagnosis of silent ACTH adenomas (44).

Respiratory system is another interesting area where Galectin-3 expression is searched by many scientists. Mathieu et al. found in their study that, nuclear Galectin-3 expression was an independent predictive factor of recurrence for adenocarcinoma and squamous cell carcinoma of the lung. Squamous cell carcinomas expressed Galectin-3 predominantly in the cytoplasm of well-differentiated areas with rare nuclear staining. On the contrary, about $50 \%$ of adenocarcinomas expressed Galectin-3 in both the nucleus and the cytoplasm, with more marked staining than in the case of squamous cell carcinomas. Galectin-3 expression was not significantly different in lymph node metastases and primary tumors and was not modified by neoadjuvant therapy. Nuclear location of Galectin-3 expression was an independent predictor of recurrence in nonsmall cell lung cancer, in particular in the case of patients having relapse-free follow-ups longer than 8 months (45).

Galectin-3 regulate epithelial proliferation/apoptosis and neutrophil activation, and are implicated in lung cancer and asthma. The role of Galectin-3 in chronic obstructive pulmonary disease (COPD), characterised by epithelial changes and neutrophil infiltration was investigated by Pilette et al. Galectin-3 expression was assessed by immunohistology in the bronchial epithelium of lung specimens from COPD patients and compared with nonsmokers and smokers without COPD. They found that, epithelial Galectin-3 immunostaining was increased only in the small airways of COPD patients when compared with nonsmokers and smokers. In patients with severe disease, an increased Galectin-3 expression and neutrophil accumulation in the small airway epithelium was demonstrated, correlating with epithelial proliferation and airway obstruction (46).

In head and neck region larynx is the most popular location, where Galectin-3 expression is searched. Choi et al. investigated Galectin-3 and Pim-1 in laryngeal squamous cell carcinoma and found that, squamous cell carcinoma showed increased Galectin-3 and Pim-1 expression in the more advanced clinical stage, tumor stage, 
and nodal status. They concluded that, Galectin-3 and Pim-1 might be used as a possible prognostic factor (47). In the study of Miranda et al. Galectin-3 overexpression in invasive laryngeal carcinoma was searched. Galectin-3 was overexpressed in invasive laryngeal carcinoma, representing an important biological marker of larynx cancer aggressiveness. Moreover, both quantitative and qualitative determination of Galectin-3 expression proved to be a good methodological strategy for the differentiation of in situ from invasive laryngeal cancer (48).

Chen et al. studied expression of Galectin-3 and Sambucus nigra agglutinin (SNA) and its clinicopathological significance in benign and malignant lesions of breast. According to their study results, the positive rates and scoring means of Galectin-3 and SNA were significantly higher in breast cancer than those in benign lesions. The scoring means of Galectin-3 and SNA expression were significantly lower in the positive cases of estrogen receptor and the negative ones of CA15-3 than those in the negative cases and the positive ones. The survival analysis of KaplanMeier showed the 5-year survival rate and mean survival period were significantly lower in the Galectin-3 or SNA expression positive cases than those in the negative cases of breast cancer. They concluded that, the positive cases of Galectin-3 and /or SNA expression might have poor prognosis (49). Mayoral et al. investigated Galectin-3 expression in breast cancer with brain metastasis and showed that, Galectin-3 was negative in normal breast tissue, but it was highly increased in breast cancer and in metastatic tissues to brain (50). Fernandez-Aguilar et al. investigated Galectin-3 expression in tubular carcinoma (TC) of breast and showed that, Galectin-3 expression was higher in TC than in grade-1 ductal carcinomas (G1). The pattern of immunostaining was also different with a focal cytoplasmic apical reinforcement in TC. The higher expression of Galectin-3 in TC and its focal staining (apical) pattern suggested that within the group of G1 carcinomas, Galectin-3 expression varied according to histological type, and might correlate with prognosis and metastatic potential (51).

D'Haene et al. studied Galectin-3 expression in normal lymphoid tissue and non-Hodgkin's and Hodgkin's lymphomas and their study showed that Diffuse Large B Cell Lymphoma could be distinguished from normal lymphoid tissue and other lymphomas on the basis of Galectin-3 expression, because Galectin-3 mRNA was expressed 3 times more in the Diffuse Large B Cell Lymphoma than in the Follicular Lymphoma and normal lymphoid tissue, lymphocytes rarely expressed Galectin-3 (52).
Shimonishi et al. searched expression of galectin-3 in intrahepatic cholangiocarcinoma (ICC) and showed that Galectin-3 was frequently and strongly expressed in the cytoplasm of well-differentiated ICCs, and its expression was significantly decreased and less intense or even absent in poorly differentiated ICCs and concluded that Galectin-3 expression in epithelial cells was up-regulated in the preneoplastic and early neoplastic stages of ICC, although Galectin-3 tended to disappear at later stages of ICC (53). Junking et al. studied Galectin-3 expression in liver fluke-associated intrahepatic cholangiocarcinoma, who had undergone surgery without pre-operative therapy. They found that, all bile duct epithelium expressed Galectin-3 with different intensities, according to the different histological subtypes and the poorlydifferentiated type expressed Galectin-3 less intensely than the papillary, well - to moderately - differentiated types. They observed the association of low Galectin-3 expression with lymphatic invasion. In their study they also showed that, suppression of Galectin-3 expression in two human cholangiocarcinoma cell lines using siRNA targeted to Galectin-3 significantly increased cell migration and invasion without alterations in cell proliferation. They concluded that, regulation of Galectin-3 expression might therefore be an alternative therapeutic approach to control metastasis of cholangiocarcinoma (54). Dechaphunkul et al. investigated differences of Galectin-3 immunostaining in patients with intrahepatic cholangiocarcinoma and adenocarcinoma liver metastasis. Their findings showed that, patients who strongly expressed Galectin-3 were positive for CK-7 and negative for CK-20 and 86\% of them were intrahepatic cholangiocarcinoma whereas only $14 \%$ were adenocarcinoma liver metastasis. They concluded that, adding Galectin-3 to CK-7 and CK20 immunohistochemistry had benefits to differentiate intrahepatic cholangiocarcinoma from adenocarcinoma liver metastasis (55).

According to many studies, chordoma arises from notochordal cell rests. Brachyury is the first specific molecule linking chordoma with the notochord, and Galectin-3 has been widely used as a marker of notochordal cells. Shen et al. studied the expression of these two molecules in classic chordoma cases and their all specimens contained atypical chordoma tumor cells set within an abundant myxoid matrix, which strongly expressed brachyury and Galectin-3. However, brachyury and Galectin-3 were not expressed in the notochordal cells. Their study results suggested that, benign notochordal cells, present as notochord rests, could undergo malignant transformation to form chordoma; however, the cause and role of brachyury and Galectin-3 expression in chordoma tumorigenesis requires further careful study (56). 
Alcendor et al. studied Kaposi's sarcoma-associated herpesvirus (KSHV) downregulation of Galectin-3 in Kaposi's sarcoma (KS). KSHV is the etiological agent of KS. They found reduced levels of Galectin-3 expression in a significant fraction of latency-associated nuclear antigen (LANA)-positive spindle cell regions in human archival KS tissue and as measured in KS tissue microarrays. They demonstrated that Galectin-3 protein expression was downregulated 10-fold in 10-day KSHV-infected dermal microvascular endothelial cells (DMVEC) accompanied by downregulation of message. There is loss of Galectin-3 staining in KSHV-infected DMVEC by dual labeled immunohistochemistry in LANA-positive spindle cells. They observed a consistent downregulation of Galectin-3 by time-course transcriptional analysis. Their data suggested that KSHV vFLIP and LANA are the viral genes targeting Galectin-3 downregulation. The contribution of host factors to the pathogenesis of KS was essential for early detection and development of innovative therapies for treatment (57).

Belezza et al. investigated Galectin-3 in granular cell tumors and, a constant diffuse positivity for Galectin-3 was found. They concluded that, Galectin-3 could help pathologists in distinguishing morphologically ambiguous granular lesions in unusual sites (58).

\section{CONCLUSION}

In this manuscript, the main data concerning the immunohistochemical expression of Galectin-3 in human cancer is reviewed. Galectin-3 is a member of galectins protein family that bind to B-galactoside containing oligosaccharides and proteins leading to their multipotent intra- and extracellular biological functions. Galectins are involved in several cellular processes including tumor cell adhesion and migration, proliferation, differentiation, angiogenesis, cancer progression and metastasis, tumor aggressiveness, modulation of apoptosis and an immune response through the induction of apoptosis in activated T-cells, highlighting their importance as cancer molecular targets. Galectin-3 protein expression evaluated utilizing immunohistochemistry techniques is a sensitive, specific, and accurate marker in certain cancers and Galectin-3 could be one of the target proteins of cancer treatment and targeting it could improve the efficacy of anticancer drug chemotherapy in several types of cancer. Because of this, Galectin-3 expression in many cancer types requires further careful study.

\section{REFERENCES}

1. Lee J, Moon C, Kim J, Jung C, Lee KH, Joo HG, Ahn M, Shin T: Immunohistochemical localization of galectin-3 in the granulomatous lesions of paratuberculosis-infected bovine intestine. J Vet Sci 2009, 10:177-180

2. Yi Wang, Pratima Nangia-Makker, Larry Tait, Vitaly Balan, Victor Hogan, Kenneth J. Pienta, Avraham Raz: Regulation of Prostate Cancer Progressionby Galectin-3. Am J Pathol 2009, 174:1515-1523

3. Sakaki M, Fukumori T, Fukawa T, Elsamman E, Shiirevnyamba A, Nakatsuji H, Kanayama HO: Clinical significance of Galectin-3 in clear cell renal cell carcinoma. J Med Invest 2010, $57: 152-157$

4. Zhang HY, Jin L, Stilling GA, Ruebel KH, Coonse K, Tanizaki Y, Raz A, Lloyd RV: RUNX1 and RUNX2 upregulate Galectin-3 expression in human pituitary tumors. Endocrine 2009, 35: 101-111

5. Chiu CG, Strugnell SS, Griffith OL, Jones SJ, Gown AM, Walker B, Nabi IR, Wiseman SM: Diagnostic utility of galectin-3 in thyroid cancer. Am J Pathol 2010, 176:2067-2081

6. Koo JS, Shin E, Hong SW: Immunohistochemical characteristics of diffuse sclerosing variant of papillary carcinoma: comparison with conventional papillary carcinoma. APMIS 2010, 118: 744-752

7. Zhu X, Sun T, Lu H, Zhou X, Lu Y, Cai X, Zhu X: Diagnostic significance of CK19, RET, galectin-3 and HBME-1 expression for papillary thyroid carcinoma. J Clin Pathol 2010, 63:786-789

8. Barut F, Onak Kandemir N, Bektas S, Bahadir B, Keser S, Ozdamar SO: Universal markers of thyroid malignancies: galectin-3, HBME-1, and cytokeratin-19. Endocr Pathol 2010, 21:80-89

9. Torregrossa L, Faviana P, Filice ME, Materazzi G, Miccoli P, Vitti P, Fontanini G, Melillo RM, Santoro M, Basolo F: CXC chemokine receptor 4 immunodetection in the follicular variant of papillary thyroid carcinoma: comparison to galectin-3 and hector battifora mesothelial cell-1. Thyroid 2010, 20:495-504

10. Saussez S, de Leval L, Decaestecker C, Sirtaine N, Cludts S, Duray A, Chevalier D, André S, Gabius HJ, Remmelink M, Leroy $X$ : Galectin fingerprinting in Warthin's tumors: lectin-based approach to trace its origin? Histol Histopathol 2010, 25:541-550

11. Ersoz S, Sert H, Yandi M, Erem C, Mungan S, Ersoz HO, Cobanoglu U, Hacihasanoglu A: The significance of Galectin-3 expression in the immunocytochemical evaluation of thyroid fine needle aspiration cytology. Pathol Oncol Res 2008, 14:457-460

12. Fassan M, Pennelli G, Pelizzo MR, Rugge M: Primary squamous cell carcinoma of the thyroid: immunohistochemical profile and literature review. Tumori 2007, 93:518-521

13. Fernandez-Ranvier GG, Khanafshar E, Tacha D, Wong M, Kebebew E, Duh QY, Clark OH: Defining a molecular phenotype for benign and malignant parathyroid tumors. Cancer 2009, 115:334-344

14. Saggiorato E, Bergero N, Volante M, Bacillo E, Rosas R, Gasparri G, Orlandi F, Papotti M: Galectin-3 and Ki-67 expression in multiglandular parathyroid lesions. Am J Clin Pathol 2006, 126:59-66 
15. Bergero N, De Pompa R, Sacerdote C, Gasparri G, Volante M, Bussolati G, Papotti M: Galectin-3 expression in parathyroid carcinoma: immunohistochemical study of 26 cases. Hum Pathol 2005, 36:908-914

16. Arfaoui-Toumi A, Kria-Ben Mahmoud L, Ben Hmida M, Khalfallah MT, Regaya-Mzabi S, Bouraoui S: Implication of the Galectin-3 in colorectal cancer development (about 325 Tunisian patients). Bull Cancer 2010, 97:1-8

17. Wu ZH, Gan L: Association of galectin-3 and E-cadherin expressions with lymph node metastasis of colon cancer. Nan Fang Yi Ke Da Xue Xue Bao 2007, 27:1731-1733

18. Huang ZL, Liu HY: Expression of galectin-3 in liver metastasis of colon cancer and the inhibitory effect of modified citrus pectin Nan Fang Yi Ke Da Xue Xue Bao 2008, 28:1358-1361

19. Miyazaki J, Hokari R, Kato S, Tsuzuki Y, Kawaguchi A, Nagao $S$, Itoh K, Miura S: Increased expression of galectin-3 in primary gastric cancer and the metastatic lymph nodes. Oncol Rep 2002, 9:1307-1312

20. Zhou JP, Yang ZL, Liu DC, Zhou JP: Expression of galectin 3 and Sambucus nigra agglutinin and their clinicopathological significance in benign and malignant lesions of stomach Zhonghua Wei Chang Wai Ke Za Zhi 2009,12:297-300

21. Okada K, Shimura T, Suehiro T, Mochiki E, Kuwano H: Reduced galectin-3 expression is an indicator of unfavorable prognosis in gastric cancer. Anticancer Res 2006, 26:1369-1376

22. Yang ZM, Wu XT, He T, Da MX, Luo T, Qian K: Study on association between the expression of galectin-3 and the peritoneal metastasis in gastric cancer. Zhonghua Wei Chang Wai Ke Za Zhi 2005, 8:151-154

23. Shibata T, Noguchi T, Takeno S, Takahashi Y, Fumoto S, Kawahara K: Impact of nuclear galectin-3 expression on histological differentiation and vascular invasion in patients with esophageal squamous cell carcinoma. Oncol Rep 2005, 13 : 235-239

24. Brazowski E, Dotan I, Tulchinsky H, Filip I, Eisenthal A: Galectin-3 expression in pouchitis in patients with ulcerative colitis who underwent ileal pouch-anal anastomosis (IPAA). Pathol Res Pract 2009, 205:551-558

25. Müller S, Schaffer T, Flogerzi B, Fleetwood A, Weimann $R$, Schoepfer AM, Seibold F: Galectin-3 modulates T cell activity and is reduced in the inflamed intestinal epithelium in IBD. Inflamm Bowel Dis 2006, 12:588-597

26. Lee JH, Zhang X, Shin BK, Lee ES, Kim I: Mac-2 binding protein and galectin-3 expression in mucinous tumours of the ovary: an annealing control primer system and immunohistochemical study. Pathology 2009, 41:229-233

27. Brustmann $\boldsymbol{H}$ : Epidermal growth factor receptor expression in serous ovarian carcinoma: an immunohistochemical study with galectin-3 and cyclin D1 and outcome. Int J Gynecol Pathol 2008, 27:380-389

28. Oishi T, Itamochi H, Kigawa J, Kanamori Y, Shimada M, Takahashi M, Shimogai R, Kawaguchi W, Sato S, Terakawa N: Galectin-3 may contribute to Cisplatin resistance in clear cell carcinoma of the ovary. Int J Gynecol Cancer 2007, 17:1040-1046
29. Devouassoux-Shisheboran M, Deschildre C, Mauduit C, Berger G, Mejean-Lebreton F, Bouvier R, Droz JP, Fénichel P, Benahmed M: Expression of galectin-3 in gonads and gonadal sex cord stromal and germ cell tumors. Oncol Rep 2006, 16: 335-340

30. Bozić M, Petronijević M, Milenković S, Atanacković J, Lazić J, Vićovac Lj: Galectin-1 and galectin-3 in the trophoblast of the gestational trophoblastic disease. Placenta 2004, 25:797-802

31. Noël JC, Chapron C, Borghese B, Fayt I, Anaf V: Galectin-3 is overexpressed in various forms of endometriosis. Appl Immunohistochem Mol Morphol 2011, 19:253-257

32. Lee JW, Song SY, Choi JJ, Choi CH, Kim TJ, Kim J, Lee JH, Kim BG, Bae DS: Decreased galectin-3 expression during the progression of cervical neoplasia. J Cancer Res Clin Oncol 2006, 132:241-247

33. Brustmann H: Galectin-3 and CD1a-positive dendritic cells are involved in the development of an invasive phenotype in vulvar squamous lesions. Int J Gynecol Pathol 2006, 25:30-37

34. Kramer MW, Kuczyk MA, Hennenlotter J, Serth J, Schilling D, Stenzl A, Merseburger AS: Decreased expression of galectin-3 predicts tumour recurrence in pTa bladder cancer. Oncol Rep 2008, 20:1403-1408

35. Merseburger AS, Kramer MW, Hennenlotter J, Serth J, Kruck S, Gracia A, Stenzl A, Kuczyk MA: Loss of galectin-3 expression correlates with clear cell renal carcinoma progression and reduced survival. World J Urol 2008, 26:637-642

36. Sakaki M, Fukumori T, Fukawa T, Elsamman E, Shiirevnyamba A, Nakatsuji H, Kanayama HO: Clinical significance of Galectin-3 in clear cell renal cell carcinoma. J Med Invest 2010, $57: 152-157$

37. Merseburger AS, Kramer MW, Hennenlotter J, Simon P, Knapp J, Hartmann JT, Stenzl A, Serth J, Kuczyk MA: Involvement of decreased Galectin-3 expression in the pathogenesis and progression of prostate cancer. Prostate 2008, 68:72-77

38. Wang Y, Nangia-Makker P, Tait L, Balan V, Hogan V, Pienta KJ, $\operatorname{Raz} A$ : Regulation of prostate cancer progression by galectin-3. Am J Pathol 2009, 174:1515-1523

39. Ostalska-Nowicka D, Nowicki M, Kondraciuk B, Partyka M, Samulak D, Witt M: Expression of galectin-3 in nephrotic syndrome glomerulopaties in children. Folia Histochem Cytobiol 2009, 47:315-322

40. Park SH, Min HS, Kim B, Myung J, Paek SH: Galectin-3: a useful biomarker for differential diagnosis of brain tumors. Neuropathology 2008, 28:497-506

41. Borges CB, Bernardes ES, Latorraca EF, Becker AP, Neder L, Chammas R, Roque-Barreira MC, Machado HR, de Oliveira RS: Galectin-3 expression: a useful tool in the differential diagnosis of posterior fossa tumors in children. Childs Nerv Syst 2011, 27:253-257

42. Rodriguez FJ, Scheithauer BW, Roncaroli F, Silva AI, Kovacs $K$, Brat DJ, Jin L: Galectin-3 expression is ubiquitous in tumors of the sellar region, nervous system, and mimics: an immunohistochemical and RT-PCR study. Am J Surg Pathol 2008, 32:1344-1352

43. Huang CX, Hou YH, Liu YS: Expression of galectin-3 correlates with apoptosis in pituitary adenoma cells. Neurosci Bull 2008, 24:34-38 
44. Jin L, Riss D, Ruebel K, Kajita S, Scheithauer BW, Horvath E, Kovacs K, Lloyd RV: Galectin-3 expression in functioning and silent ACTH-producing adenomas. Endocr Pathol 2005, 16: 107114

45. Mathieu A, Saal I, Vuckovic A, Ransy V, Vereerstraten P, Kaltner H, Gabius HJ, Kiss R, Decaestecker C, Salmon I, Remmelink M: Nuclear galectin-3 expression is an independent predictive factor of recurrence for adenocarcinoma and squamous cell carcinoma of the lung. Mod Pathol 2005, 18:1264-1271

46. Pilette C, Colinet B, Kiss R, André S, Kaltner H, Gabius HJ, Delos M, Vaerman JP, Decramer M, Sibille Y: Increased galectin-3 expression and intra-epithelial neutrophils in small airways in severe COPD. Eur Respir J 2007, 29:914-922

47. Choi JY, Cho SI, Do NY, Kang CY, Lim SC: Clinical significance of the expression of galectin-3 and Pim-1 in laryngeal squamous cell carcinoma. J Otolaryngol Head Neck Surg 2010, 39:28-34

48. Miranda FA, Hassumi MK, Guimarães MC, Simões RT, Silva TG, Lira RC, Rocha AM, Mendes CT Jr, Donadi EA, Soares CP, Soares EG: Galectin-3 overexpression in invasive laryngeal carcinoma, assessed by computer-assisted analysis. J Histochem Cytochem 2009, 57:665-673

49. Chen G, Zou Q, Yang Z: Expression of galectin-3 and Sambucus nigra agglutinin and its clinicopathological significance in benign and malignant lesions of breast. Zhong Nan Da Xue Xue Bao Yi Xue Ban 2010, 35:584-589

50. Mayoral MA, Mayoral C, Meneses A, Villalvazo L, Guzman A, Espinosa B, Ochoa JL, Zenteno E, Guevara J: Identification of galectin-3 and mucin-type O-glycans in breast cancer and its metastasis to brain. Cancer Invest 2008, 26:615-623

51. Fernandez-Aguilar S, Noël JC: Expression of cathepsin D and galectin 3 in tubular carcinomas of the breast. APMIS 2008, $116: 33-40$
52. D'Haene N, Maris C, Sandras F, Dehou MF, Remmelink M, Decaestecker C, Salmon I: The differential expression of Galectin-1 and Galectin-3 in normal lymphoid tissue and nonHodgkin's and Hodgkin's lymphomas. Int J Immunopathol Pharmacol 2005, 18:431-443

53. Shimonishi T, Miyazaki K, Kono N, Sabit H, Tuneyama K, Harada K, Hirabayashi J, Kasai K, Nakanuma Y: Expression of endogenous galectin-1 and galectin-3 in intrahepatic cholangiocarcinoma. Hum Pathol 2001, 32:302-310

54. Junking M, Wongkham C, Sripa B, Sawanyawisuth K, Araki N, Wongkham S: Decreased expression of galectin-3 is associated with metastatic potential of liver fluke-associated cholangiocarcinoma. Eur J Cancer 2008, 44:619-626

55. Dechaphunkul A, Kanngurn S, Dechsukhum C, Tanutit P, Khow-Ean U, Sunpaweravong P: The significance of galectin-3 immunohistochemistry, clinical characteristics and liver imaging in differentiating intrahepatic cholangiocarcinoma from adenocarcinoma liver metastasis. J Med Assoc Thai 2010, 93: 523-528

56. Shen J, Li CD, Yang HL, Lu J, Zou TM, Wang DL, Deng M: Classic chordoma coexisting with benign notochordal cell rest demonstrating different immunohistological expression patterns of brachyury and galectin-3. J Clin Neurosci 2011, 18:96-99

57. Alcendor DJ, Knobel SM, Desai P, Zhu WQ, Vigil HE, Hayward GS: KSHV downregulation of galectin-3 in Kaposi's sarcoma. Glycobiology 2010, 20:521-532

58. Bellezza G, Colella R, Sidoni A, Del Sordo R, Ferri I, Cioccoloni $C$, Cavaliere A: Immunohistochemical expression of Galectin-3 and HBME-1 in granular cell tumors: a new finding. Histol Histopathol 2008, 23:1127-1130 